\title{
Double-surface intensive phototherapy versus single-surface conventional phototherapy in treatment of neonatal hyperbilirubinemia
}

\begin{abstract}
Nashwan M. Al-Hafidh ${ }^{a}$, Ziad K. Ali ${ }^{b}$, Ruthwan S. Saeed ${ }^{b}$
From the aDepartment of Medicine, Nineveh College of Medicine, University of Mosul, ${ }^{\mathrm{b}} \mathrm{Ibn}$ Al-Atheer Pediatric Hospital, Mosul. Correspondence: Nashwan M. Al-Hafidh. Department of Medicine, Nineveh College of Medicine, University of Mosul, Mosul, Iraq. Email: nashwan_ped@yahoo.com.
\end{abstract}

(Ann. Coll. Med. Mosul 2013; 39 (1): 25-31).

Received: $18^{\text {th }}$ Jan. 2012; Accepted: $15^{\text {th }}$ Jul. 2012.

\section{ABSTRACT}

Objective: To compare the efficacy of double-surface intensive phototherapy (DSIPT) and single-surface conventional phototherapy (SSCPT) in treatment of neonatal jaundice.

Patients and methods: This is a case control study conducted in Ibn Al Atheer Pediatric Hospital (Mosul) included 110 jaundiced neonates subjected to the newly used (DSIPT) during the period between $1^{\text {st }}$ of Jan. 2011 to $30^{\text {th }}$ of June 2011 compared to 142 jaundiced neonates underwent phototherapy using SSCPT during the period between $1^{\text {st }}$ of July 2010 to $31^{\text {st }}$ of December 2010. Patients with acute bilirubin encephalopathy, sepsis, meningitis and asphyxia were excluded from this study as well as those aged $>1$ week. The medical files data of included infants were analyzed regarding their gestational age, body weight, sex, age, type of feeding and total serum bilirubin level (TSB) at initiation of phototherapy. Levels of TSB at intervals of approximately 6 hours during the first 24 hours of treatment, the need of exchange transfusion and duration of hospitalization were registered.

Results: Demographic characteristics apart from gestational age were similar in both groups. The initial mean serum bilirubin level had no statistically significant difference between DSIPT and the SSCPT group. DSIPT group had significantly greater TSB decline rates than SSCPT in term and preterm infants with hyperbilirubinemia. The mean percentages of TSB decline per hour was significantly higher within 6,12 , and 24 hours after starting DSIPT compared to SSCPT type. The mean percentages of TSB decline of DSIPT group within the second 12 hours after phototherapy was significantly higher and more than double the value of SSCPT type ( $43.45 \pm 14.83$ vs. $17.03 \pm 14.22, p<0.001)$. Duration of hospitalization was significantly shorter in DSIPT subjected infants. At initial TSB level between $20-25 \mathrm{mg} / \mathrm{dl}$ exchange transfusion was avoidable among intensively treated patients whereas it was inevitable in $86.36 \%$ of patients in the SSCPT group. At TSB on exchange line $91.56 \%$ of infants received SSCPT type required an exchange transfusion whereas such intervention was eliminated in patients treated by DSIPT.

Conclusions: DSIPT was significantly more effective than SSCPT in treatment of neonatal hyperbilirubinemia. When initial TSB level is on and below exchange line on nomogram, exchange transfusion can be avoided with the use of DSIPT.

$$
\begin{aligned}
& \text { العلاج الضوئي ثنائي السطح المكثف مقارنة بالعلاج الضوئي }
\end{aligned}
$$

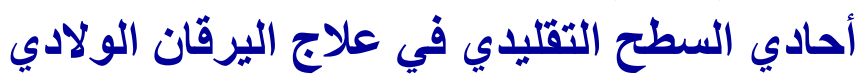

الخلاصة

هدف الدراسة: لمقارنة فعالية العلاج الضوئي ثنائي السطح المكثف بالعلاج الضوئي أحادي السطح التقليدي في علاج اليرقان الو لادي.

طريقة البحث والمشاركون: هذه دراسة لحالات أدخلت الى مستشفى ابن الأثثر للأطفال (الموصل) خلال الفترة بين الأول من

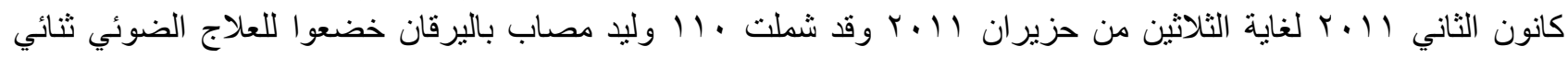




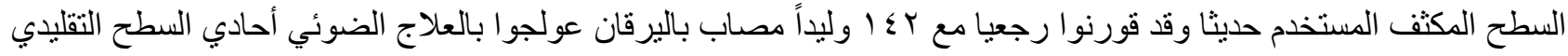

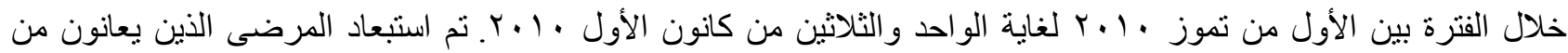

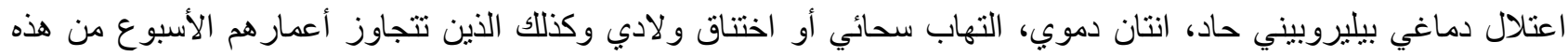

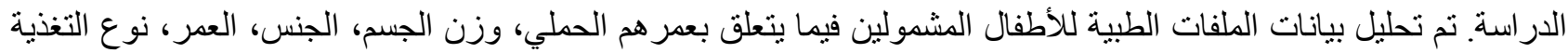

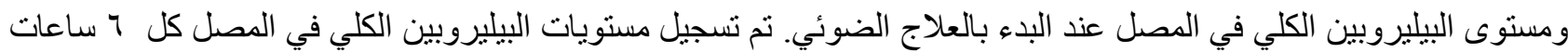
تقريبا خلال الـ \& r ساعة الأولى من العلاج، كما سجلت الحاجة لعمليات تبديل الدم ومدة الاستشفاء.

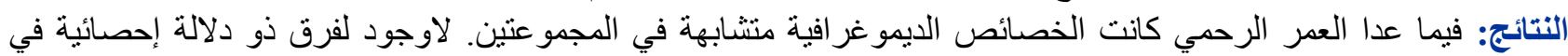

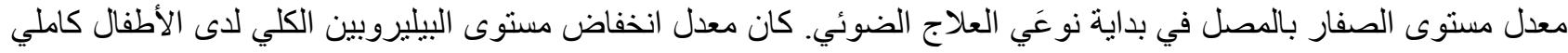

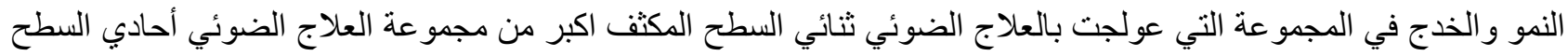

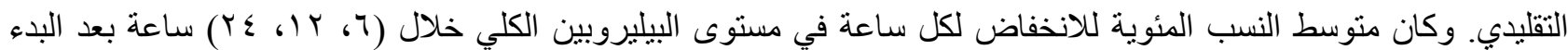

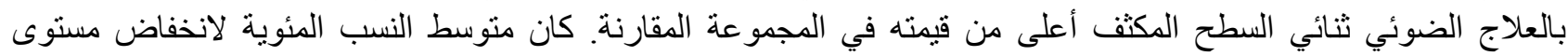

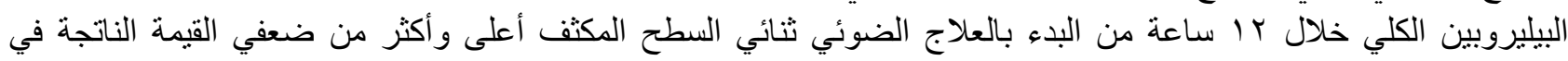

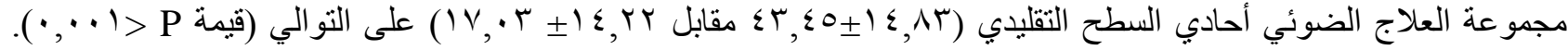

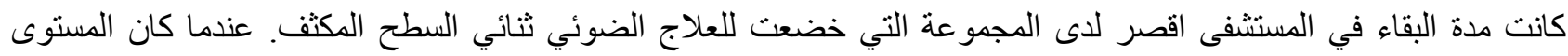

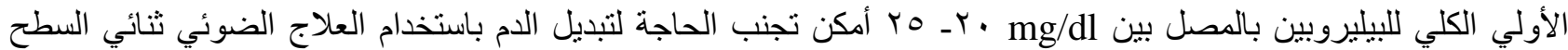

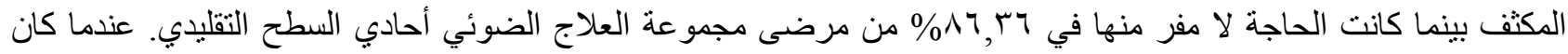

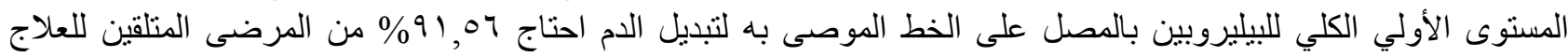
الضوئي أحادي السطح التقليدي اللى إجراء تبديل للام في حين نم استبعاد مثل هذا التداخل لدى المعالجين بالعلاج الضوائي ثنائي السطح المكثف. الطنائ.

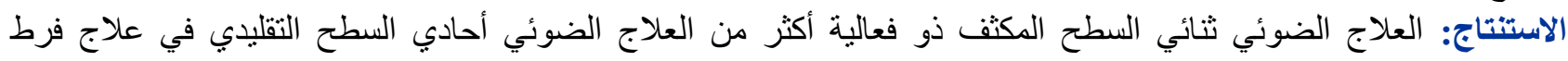

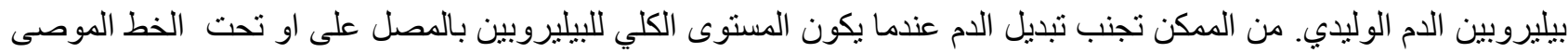

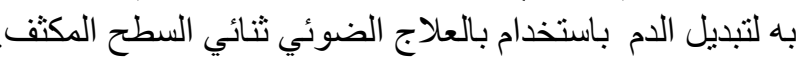

$\mathrm{J}$ aundice is observed during the $1^{\text {st }}$ wk of life in approximately $60 \%$ of term infants and $80 \%$ of preterm infants, $5-10 \%$ of all newborns require intervention for pathological jaundice ${ }^{(1,2)}$.

The sunlight fading effect on the yellow skin color of jaundiced newborns was discovered accidentally by Sister J. Ward an English nurse in 1956, an observation that led to the discovery that visible light could lower serum bilirubin levels in newborn infants ${ }^{(3,4)}$. The very first phototherapy unit incorporating an artificial light source was devised and tested by Cremer et al at Rochford Hospital in $1958^{(5)}$. Phototherapy is the most common therapeutic intervention used for the treatment of hyperbilirubinemia and it is used to prevent the neurotoxic effects of bilirubin ${ }^{(6,7)}$.

Conventional or standard daylight phototherapy units should deliver a spectral irradiance (measured at the level of the infant) of 8 to $10 \mu \mathrm{W}$ per square centimeter per nanometer in the 430to-490-nm band ${ }^{(8)}$. The American Academy of Pediatrics (AAP) defines intensive phototherapy as irradiance in the blue-green spectrum (wavelengths of approximately $430-490 \mathrm{~nm}$ ) of at least $30 \mu \mathrm{W}$ per square centimeter per nanometer (9). This may be achieved by using light sources placed above and beneath the infant ${ }^{(8)}$.

Hyperbilirubinemia may lead to encephalopathy at any time during the neonatal period. Lethargy, poor feeding, and loss of the Moro reflex are common initial manifestations ${ }^{(1)}$. Immediate exchange transfusion is recommended in any infant who is jaundiced and has the manifestation of acute bilirubin encephalopathy even if the TSB is falling ${ }^{(9)}$. Exchange transfusion should also be considered if the TSB remains above the indicated exchange level after 6 hours of intensive phototherapy ${ }^{(1)}$.

This study was done for the purpose of comparing the efficacy of recently introduced intensive phototherapy device with the already in use conventional phototherapy type.

\section{PATIENTS AND METHODS}

This study analyzed the medical case files of all newborn infants aged $\leq 1$ week with neonatal 
hyperbilirubinemia requiring phototherapy who were admitted to Neonatal Care Unit (NCU) in Ibn Al Atheer pediatric hospital (Mosul), between $1^{\text {st }}$ of July 2010 to $30^{\text {th }}$ of June 2011. Patients with acute bilirubin encephalopathy, sepsis, meningitis, asphyxia, were excluded from this study.

During the period between $1^{\text {st }}$ of July 2010 to $31^{\text {st }}$ of December 2010 only conventional phototherapy type was available. The first studied group (142 patients) was selected from this period and was compared to the second group (110 patients) who was treated by intensive phototherapy during the period between $1^{\text {st }}$ of Jan 2011 to $30^{\text {th }}$ of June 2011. All infants' gestational age, body weight, sex, ages at phototherapy, type of feeding, total serum bilirubin level at initiation of phototherapy and duration of hospitalization were registered.

Blood examination for all admitted infants included blood group, total serum bilirubin (TSB) concentration, complete blood picture, reticulocyte count as well as blood group of the infant's mother. Non hemolytic cause was labeled if isolated hyperbilirubinemia was reported with normal heamoglobin and reticulocyte count.

Levels of TSB were plotted on appropriate guidelines charts recommended by the American Academy of Pediatrics Subcommittee on Hyperbilirubinemia which indicate the need of phototherapy or exchange transfusion. Standard AAP guidelines were used to start and stop phototherapy. If the initial TSB level was high $(\geq 20$ $\mathrm{mg} / \mathrm{dl}$ ) or the TSB level is on exchange line on chart according to gestational age and post conceptual age in hours, phototherapy was applied and the patient companion is immediately contacted to provide compatible blood for possible exchange transfusion.

Level of TSB was measured by Bilirubin meter (photomech 301-A/D, Optima Inc, Tokyo, Japan), assessed and calibrated regularly by laboratory technician or trained pediatric permanent resident. After initiating phototherapy TSB concentration was again determined at intervals of approximately 6 hours during the first 24 hours of treatment. After this period, TSB concentration is checked approximately every 24 hours until phototherapy is discontinued. If after the initial 6 hours of phototherapy TSB level remained above the indicated exchange level or the patient developed manifestations compatible with diagnosis of acute bilirubin encephalopathy an exchange transfusion was performed.

Conventional overhead phototherapy used in this study was of Micro-Lite® PTS68-1 phototherapy system type (Germany) which have been equipped with three lamps of EXZ quartz halogen emitting a white light of $400-520$ nanometer wavelength having an intensity of at least $10 \mu \mathrm{w} / \mathrm{cm}^{2} / \mathrm{nm}$ placed at $43 \mathrm{~cm}$ from the center of mattress. Lamps were replaced before the recommended replacement usage time of 1000 hours.

Intensive phototherapy used was Bilisphere $360^{\circ}$ which is registered trademarks of Novos Ltd. (Ankara/Turkey) consisting of 16 pieces of blue light fluorescent tubes with spectral irradiance 420 $\mathrm{nm}$ to $500 \mathrm{~nm}$ and intensity of $30 \mu \mathrm{W} / \mathrm{cm} 2 / \mathrm{nm}$, encircling the patient throughout $360^{\circ}$ and located at distance of 25 centimeter from the center of the bed which consist of a hammock made from fabric network overlying glassy bed through which the light in the lower surface of the bed is transmitted to the infant. At the end of this study the lamp usage time displayed by each of the two used intensive phototherapy units were 1180 hours and 896 hours respectively which were less than recommended replacement lamp usage time of 1980 hours.

During both types of phototherapy all infants were exposed, completely unclothed with their eyes and genital regions covered. Phototherapy was administered continuously except during feeding, diapering, physical examination and capillary blood sampling.

Routine nursing care was similarly applied to all infants; feeding on demand was encouraged and if the patient showed clinical signs of dehydration, intravenous fluids were initiated.

Results are expressed in terms of the mean \pm standard deviation and in numbers and percentages (for categorical variables). Data were computed through using Statistical Package for Social Sciences (SPSS, version 11.5). Independent sample $T$ test was used to test the different between means. A p-value of less than 0.05 was defined as statistically significant.

The study was approved by the local ethical committee in Nineveh College of Medicine and Local Health Authority. 


\section{RESULTS}

During the period of this study, 142 neonates subjected to SSCPT, whereas 110 neonates underwent DSIPT type. Apart from significant gestational age difference there were no significant demographic differences in term of age at phototherapy, birth weight, sex, and feeding type between the compared groups (Table 1).

Both groups had no significant difference regarding their initial TSB level. Mean TSB Percentages decline rate per hour within first 6 and second 6 and 12 hours after phototherapy were significantly greater in DSIPT group compared to SSCPT group. The mean TSB percentages decline within the second 12 hours after phototherapy among DSIPT treated infants was significantly higher and more than double the value of SSCPT type $(43.45 \pm 14.83$ vs. $17.03 \pm$ 14.22; $\mathrm{p}<0.001)$ respectively. The mean TSB decline rate in term of $\mathrm{mg} / \mathrm{d} / \mathrm{hour}$ within second 6 hours after starting DSIPT was significantly higher than SSCPT group. That rate was approximately twice the value of SSCPT group $(0.61 \pm 0.34$ vs. $0.31 \pm 0.31 ; p<0.046)$, likewise in the second 12 hours after therapy the mean TSB decline rate in patients using DSIPT type was $>$ four folded the value of SSCPT group ( $0.49 \pm 0.24$ vs. $0.11 \pm 0.10$; $\mathrm{p}<0.001$ ) respectively (Table 2 ). Duration of hospitalization was significantly shorter in DSIPT than SSCPT subjected infants $(2.10 \pm 1.29$ vs. $3.01 \pm 1.49 ; p<0.001$ ) respectively.

The main TSB decline rate in term of $\mathrm{mg} / \mathrm{d} / \mathrm{hour}$ within the second 12 hours after initiating DSIPT was significantly higher than SSCPT group in both hemolytic and non hemolytic categorical causes of hyperbilirubinemia among studied infants. The same rate was also significantly higher in DSIPT group compared to SSCPT group among the enrolled full term and preterm infants $(p<0.001)$ (Table 3).

Table 1. Demographic characteristics of neonates subjected to two types of phototherapy.

\begin{tabular}{|c|c|c|c|c|c|c|}
\hline & \multicolumn{2}{|c|}{$\begin{array}{l}\text { SSCPT type } \\
(N=142)\end{array}$} & \multicolumn{2}{|c|}{$\begin{array}{l}\text { DSIPT type } \\
(N=110)\end{array}$} & \multirow[t]{2}{*}{ P- value } \\
\hline & & No. & $\%$ & No. & $\%$ & \\
\hline Gestation & $\begin{array}{l}\text { Full term } \\
\text { Premature }\end{array}$ & $\begin{array}{c}116 \\
26\end{array}$ & $\begin{array}{l}81.70 \\
11.30\end{array}$ & $\begin{array}{c}100 \\
10\end{array}$ & $\begin{array}{l}90.90 \\
9.10\end{array}$ & $0.038^{*}$ \\
\hline Gender & $\begin{array}{l}\text { Male } \\
\text { Female }\end{array}$ & $\begin{array}{l}82 \\
60\end{array}$ & $\begin{array}{l}57.75 \\
42.25\end{array}$ & $\begin{array}{l}69 \\
41\end{array}$ & $\begin{array}{l}62.73 \\
37.27\end{array}$ & $0.424^{*}$ \\
\hline Feeding & $\begin{array}{l}\text { Breast feeding } \\
\text { Bottle feeding } \\
\text { Mixed feeding }\end{array}$ & $\begin{array}{c}103 \\
26 \\
13 \\
\end{array}$ & $\begin{array}{l}72.53 \\
18.31 \\
9.155\end{array}$ & $\begin{array}{l}86 \\
12 \\
12 \\
\end{array}$ & $\begin{array}{l}78.18 \\
10.91 \\
10.91\end{array}$ & $0.258^{*}$ \\
\hline & & \multicolumn{2}{|c|}{ Mean \pm SD } & \multicolumn{2}{|c|}{ Mean \pm SD } & \\
\hline \multicolumn{2}{|c|}{ Age at phototherapy (hours) } & \multicolumn{2}{|c|}{$108.09 \pm 41.48$} & \multicolumn{2}{|c|}{$110.60 \pm 36.48$} & $0.652^{\star *}$ \\
\hline \multicolumn{2}{|c|}{ Body weight } & \multicolumn{2}{|c|}{$3.02 \pm 0.63$} & \multicolumn{2}{|c|}{$3.18 \pm 0.64$} & $0.068^{\star \star}$ \\
\hline
\end{tabular}

*Chi -square test used. **Independent sample T test was used.

Table 2. Total serum bilirubin decline after starting 2 different phototherapy types, in relation to duration of phototherapy (Mean \pm SD).

\begin{tabular}{|c|c|c|c|}
\hline & $\begin{array}{l}\text { SSCPT type } \\
\quad(\mathrm{N}=142)\end{array}$ & $\begin{array}{l}\text { DSIPT type } \\
(\mathrm{N}=110)\end{array}$ & P-value* \\
\hline Initial TSB level (mg/dl) & $19.56 \pm 5.35$ & $18.85 \pm 4.57$ & 0.253 \\
\hline \multicolumn{4}{|l|}{ After phototherapy } \\
\hline Mean TSB decline rate within first 6 hour (\%/hour) & $1.51 \pm 1.55$ & $4.23 \pm 2.02$ & 0.012 \\
\hline Mean TSB decline rate within second 6 hours. (\%/hour) & $1.26 \pm 0.79$ & $3.28 \pm 1.67$ & 0.007 \\
\hline Mean TSB decline rate within second 12 hours (\%/hour) & $0.77 \pm 0.66$ & $2.39 \pm 1.1$ & $<0.001$ \\
\hline Mean TSB percentages decline within first 6 hour & $14.72 \pm 10.22$ & $21.89 \pm 10.03$ & 0.164 \\
\hline Mean TSB percentages decline within second 6 hours & $15.10 \pm 9.46$ & $27.74 \pm 12.26$ & 0.070 \\
\hline Mean TSB percentages decline within second 12 hours & $17.03 \pm 14.22$ & $43.45 \pm 14.83$ & $<0.001$ \\
\hline Mean TSB decline rate within first 6 hours,( mg/dl/hour) & $0.73 \pm 0.51$ & $0.81 \pm 0.38$ & 0.746 \\
\hline Mean TSB decline within second 6 hours,(mg/dl/hour) & $0.31 \pm 0.31$ & $0.61 \pm 0.34$ & 0.046 \\
\hline Mean TSB decline within second 12 hours,(mg/dl/hour) & $0.11 \pm 0.10$ & $0.49 \pm 0.24$ & $<0.001$ \\
\hline
\end{tabular}

*Independent samples $T$ test was used. 
Among neonates not required an exchange transfusion, although there was no statistically significant difference between the compared types of phototherapy among neonates who had initial TSB level between $10-15 \mathrm{mg} / \mathrm{dl}$, the main TSB decline rate at initial bilirubin level between 15-25 $\mathrm{mg} / \mathrm{dl}$ was significantly higher in DSIPT group compared to SSCPT group levels within the second 12 hours post therapy. At initial TSB level of $20-25 \mathrm{mg} / \mathrm{dl}$ the bilirubin decline rate in this study was approximately $1 \mathrm{mg} / \mathrm{dl} /$ hour in DSIPT group compared to $0.36 \pm 0.13 \mathrm{mg} / \mathrm{dl} / \mathrm{hour}$ in SSCPT group ( $p=0.029$ ) (Table 4).

Failure of phototherapy treatment was the only indication for an exchange transfusion in this study given that manifestation of acute bilirubin encephalopathy was not reported in both groups.
With initial TSB level between 20-25 mg/dl exchange transfusion was avoidable among intensively treated patients whereas it was inevitable in $86.36 \%$ of patients in the SSCPT group. Level of TSB higher than $25 \mathrm{mg} / \mathrm{dl}$ was totally not responding to SSCPT compared to failure of DSIPT in only $1.81 \%$ of comparable studied patients. Over all nearly half of patients 67 (47, 18\%) were urged to underwent exchange transfusion in the SSCPT group compared to 2 (1.81\%) patients in DSIPT group. With high TSB levels on exchange line exchange transfusion was required in $91.56 \%$ of neonates treated by SSCPT compared to total prevention of the exchange transfusion need in those subjected to DSIPT (Table 5).

Table 3. Total serum bilirubin decline rate ( $\mathrm{mg} / \mathrm{dl} / \mathrm{hour}$ ) within the second 12 hour after starting 2 different phototherapy types.

\begin{tabular}{|c|c|c|c|c|c|c|c|}
\hline & \multicolumn{6}{|c|}{ Total serum bilirubin decline rate (mg/dl/hour) } & \multirow{3}{*}{ P-value* } \\
\hline & \multicolumn{3}{|c|}{ SSCPT type $(N=142)$} & \multicolumn{3}{|c|}{ DSIPT type $(\mathrm{N}=110)$} & \\
\hline & No. & $\%$ & Mean \pm SD & No. & $\%$ & Mean \pm SD & \\
\hline \multicolumn{8}{|l|}{ Gestational age } \\
\hline Full term & 116 & 81.70 & $0.13 \pm 0.10$ & 100 & 90.90 & $0.48 \pm 0.23$ & $<0.001$ \\
\hline Premature & 26 & 18.30 & $0.06 \pm 0.027$ & 10 & 9.10 & $0.59 \pm 0.28$ & 0.006 \\
\hline \multicolumn{8}{|l|}{ Etiology } \\
\hline Hemolytic & 41 & 28.87 & $0.13 \pm 0.09$ & 20 & 18.18 & $0.51 \pm 0.13$ & 0.001 \\
\hline Non-hemolytic & 101 & 71.13 & $0.11 \pm 0.11$ & 90 & 81.82 & $0.47 \pm 0.24$ & $<0.001$ \\
\hline
\end{tabular}

* Independent sample T test was used.

Table 4. Total serum bilirubin decline rate $(\mathrm{mg} / \mathrm{dl} / \mathrm{hour}$ ) within the second 12 hour after starting 2 different phototherapy types, among neonates not required an exchange transfusion.

\begin{tabular}{|l|c|c|c|c|c|c|c|}
\hline \multirow{2}{*}{ Initial TSB level (mg/dl) } & \multicolumn{5}{|c|}{ Total serum bilirubin decline rate (mg/dl/hour) } & \multirow{2}{*}{ P-value* } \\
\cline { 2 - 7 } & \multicolumn{3}{|c|}{ SSCPT type (N=75) } & \multicolumn{3}{c|}{ DSIPT type (N=108) } & \\
\cline { 2 - 7 } & No. & $\%$ & Mean \pm SD & No. & $\%$ & Mean \pm SD & \\
\hline $10-15$ & 32 & 42.66 & $0.17 \pm 0.25$ & 14 & 12.96 & $0.29 \pm 0.21$ & 0.134 \\
\hline $15-20$ & 37 & 49.33 & $0.21 \pm 0.10$ & 65 & 60.19 & $0.53 \pm 0.30$ & $<0.001$ \\
\hline $20-25$ & 6 & 8 & $0.36 \pm 0.13$ & 19 & 17.59 & $0.93 \pm 0.303$ & 0.029 \\
\hline
\end{tabular}

*Independent samples T test was used.

Table 5. Percentages of neonates subjected to exchange transfusion after using two types of phototherapy.

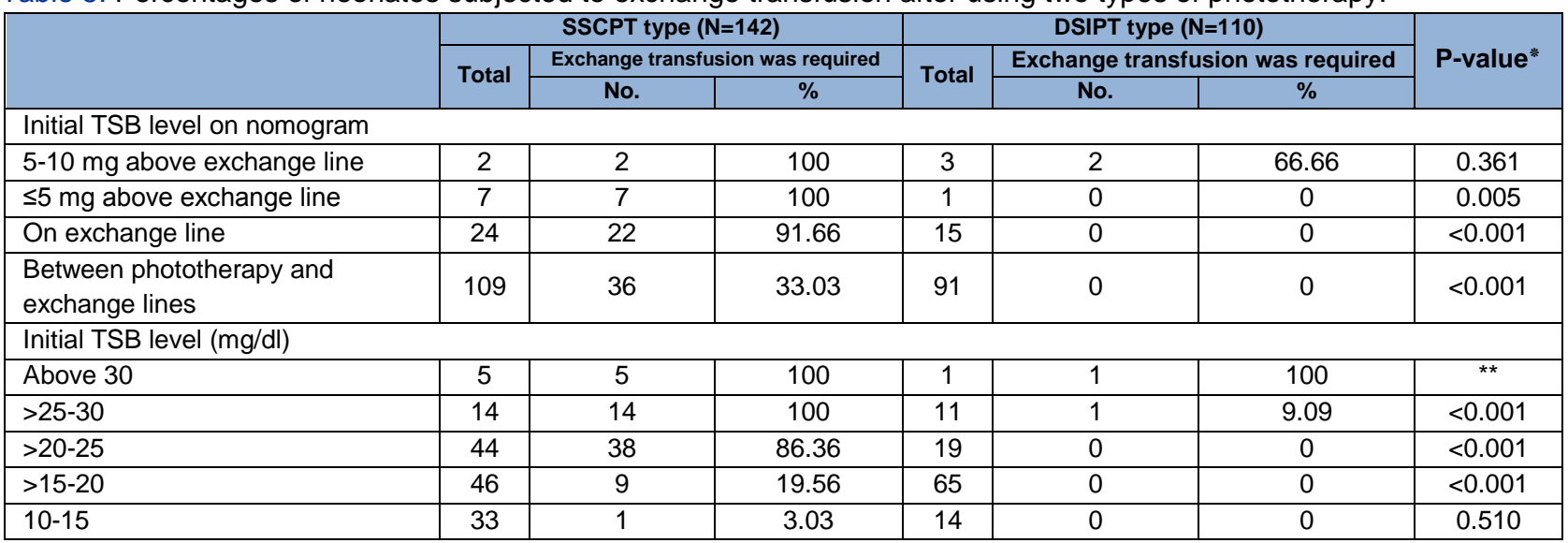

* Chi -square test used. ${ }^{* \star}$ No statistics can be computed because exchange transfusion application was constant in both groups. 


\section{DISCUSSION}

The efficacy of phototherapy is dependent on the color (wavelength), intensity (irradiance) of the light emitted during phototherapy, the exposed body surface area and the infant's distance from the light ${ }^{(8,10)}$, blue lamps are most effective in reducing hyperbilirubinemia ${ }^{(8,11-12)}$. The nearer the lights source to the infant, the greater the irradiance ${ }^{(8)}$. In general the demonstrated significant differences between the compared studied groups in favor of DSIPT type are collectively attributed to these factors. These factors were responsible for the significantly higher percentages of bilirubin decline /hour found in studied DSIPT group compared to SSCPT group within 6, 12, 24 hours after commencing phototherapy. Those differences reflected the significant effectiveness of the used DSIPT type in TSB reduction regardless the cause of neonatal hyperbilirubinemia.

Nuntnarumit $P$ et al in Thailand, found that with intensity of $9-10 \mu \mathrm{w} / \mathrm{cm}^{2} / \mathrm{nm}$ the bilirubin reduction rate after therapy was $0.14 \pm 0.1 \mathrm{mg} / \mathrm{d} / \mathrm{h}$ on day 1 of therapy ${ }^{(13)}$, which was comparable to $0.11 \pm$ $0.10 \mathrm{mg} / \mathrm{dl} / \mathrm{h}$ rate of SSCPT studied group. With the same intensity of $\quad \begin{array}{llll}-10 & \mu \mathrm{w} / \mathrm{cm}^{2} / \mathrm{nm}\end{array}$ Nuntnarumit $\mathrm{P}$ et al observed that the bilirubin reduction rate was $0.22 \pm 0.12 \mathrm{mg} / \mathrm{dl} / \mathrm{h}$ on day 1 of therapy with adapted double phototherapy placing daylight fluorescent lamps $38 \mathrm{~cm}$ above and $32 \mathrm{~cm}$ below the crib ${ }^{(13)}$, a greater value of bilirubin reduction of $0.49 \pm 0.24 \mathrm{mg} / \mathrm{dl} / \mathrm{h}$ within second 12 hour of the DSIPT was recorded in our study probably attributed to difference in light intensity and shorter distance from the light. There is a direct relationship between the irradiance used and the rate at which the level of total serum bilirubin declines ${ }^{(8)}$.

When single-surface intensive phototherapy compared to double-surface intensive phototherapy equipped with a mixture of deep blue and day light phototherapy cumulative percent 48 hour decline (\%) was $43.1 \pm 12.4$ among singlesurface intensive phototherapy shown in the study of Boonyarittipong $P$ et al in Bangkok ${ }^{(14)}$, almost equivalent percentage $(43.45 \pm 14.83)$ was achieved 24 hour earlier in DSIPT studied group, this difference probably because of type of light used and more surface area exposed to phototherapy in this study. Cumulative percent 24 hour decline (\%) was $34.1 \pm 11.1$ among double-surface intensive phototherapy used in the same Bangkok study ${ }^{(14)}$, which is also less than the mentioned value of the enrolled DSIPT group, these differences may be attributed to type of light used. Intensive phototherapy can result in a bilirubin decrement of 30 to $40 \%$ in the first 24 hours ${ }^{(8)}$. The level of serum bilirubin immediately after the exchange transfusion declines to levels that are about half of those before the exchange ${ }^{(15)}$ a level which is achieved within the second 12 hour in this study using DSIPT type.

Although there was no significant difference in the TSB decline rate in term of $\mathrm{mg} / \mathrm{d} / / \mathrm{h}$ in the first 6 hour between the studied group, the cumulative bilirubin decline rate $(\mathrm{mg} / \mathrm{dl} / \mathrm{h})$ after first 6 hour in DSIPT cases was not only significantly higher $(p=$ 0.046) than SSCPT group but more importantly it decreased the need for exchange transfusion to $1.81 \%$ in DSIPT group versus $47.18 \%$ of compared SSCPT group. On other hand this result supports the accurate time selection of 6 hours recommended by AAP to determine exchange transfusion requirement.

Similar to this study other investigators confirmed that double surface phototherapy is more efficient than single surface phototherapy in term as well as in preterm infants ${ }^{(14,16-18)}$. Duration of phototherapy was shorter in DSIPT group compared to SSCPT group in this study likewise in other studies ${ }^{(13,16,-}$ 18). Significant bilirubin decline rate $(\mathrm{mg} / \mathrm{dl} / \mathrm{h})$ difference was verified between DSIPT and SSCPT in both hemolytic and none a hemolytic category which was comparable to the finding of other researchers ${ }^{(14,16-18)}$.

Because phototherapy works on bilirubin present in the skin and superficial subcutaneous tissue, the more bilirubin present at those sites (i.e., the higher the total serum bilirubin level), the more effective phototherapy will be ${ }^{(8)}$. This may explain the non significant difference between the two studied groups at initial TSB level of $10-15 \mathrm{mg} / \mathrm{dl}$ whereas it supported our findings of direct relationship of bilirubin decline rate to initial TSB level in both studied groups.

Among DSIPT studied group no patient required exchange transfusion when TSB level was on exchange line or was $\leq 25 \mathrm{mg} / \mathrm{dl}$, this is in concordance with AAP recommendations that if the TSB is at a level at which exchange transfusion is recommended or if the TSB level is $25 \mathrm{mg} / \mathrm{dl}$ or 
higher at any time, it is a medical emergency and the infant should be admitted for intensive phototherapy ${ }^{(9)}$ and it is particularly important to use lamps with blue emission ${ }^{(8)}$. The use of phototherapy has decreased the need for exchange transfusion in term and preterm infants with hemolytic and nonhemolytic jaundice ${ }^{(1)}$. Intensive phototherapy may eliminate the need for exchange transfusion ${ }^{(12)}$.

\section{CONCLUSIONS}

This study demonstrated that DSIPT was more effective than SSCPT in treatment of neonatal hyperbilirubinemia in the first week of life. It clearly showed that DSIPT significantly reduced the exchange transfusion requirement among infants with high TSB level compared to SSCPT type.

\section{RECOMMENDATION}

We recommend DSIPT use when initial TSB level is on and below exchange line on nomogram, to reduce the need for exchange transfusion.

\section{REFERENCS}

1. Ambalavanan N, Carlo WA. Jaundice and Hyperbilirubinemia in the Newborn, kernicterus. In: Kliegman R M, Stanton BF, St Geme III J W, Schor N F Behrman R E, editors. Nelson Textbook of Pediatrics. $19^{\text {th }}$ ed. Philadelphia: Saunders Elsevier; 2011.p.603612.

2. Mishra S, Agarwal R, Deorari A K, Paul V K. Jaundice in the newborns. Indian J Pediatr. 2008 Feb; 75(2):157163.

3. Maisels MJ. Phototherapy-traditional and nontradetional. Journal of Perinatology 2001; 21(Suppl 1): 93-97.

4. Dobbs R H, Cremer R J. Phototherapy. Archives of Disease in Childhood.1975; 50, 833-836.

5. Cremer R J, Perryman P W, Richards D H. Influence of light on the hyperbilirubinaemia of infants. Lancet 1958; 24(1):1094-1097.

6. Vreman $H \quad J$, Wong $R \quad J$, Stevenson $D \quad K$. Phototherapy: current methods and future directions. Semin Perinatol. 2004 Oct; 28(5):326-333.
7. Ruud H T W. Phototherapy for neonatal jaundice-therapeutic effects on more than one level. Semin Perinatol. 2010 Jun; 34(3):231-234.

8. Maisels MJ, McDonagh AF. Phototherapy for Neonatal Jaundice. N Engl J Med. 2008; 358:920-928.

9. American Academy of Pediatrics Subcommittee on Hyperbilirubinemia. Management of hyperbilirubinemia in the newborn infant 35 or more weeks of gestation. Pediatrics. 2004; 114:297-316.

10. Chang YS, Hwang JH, Kwon HN, Choi CW, Ko SY, Park WS, et al. In vitro and in vivo efficacy of new blue light emitting diode phototherapy compared to conventional halogen quartz phototherapy forneonatal jaundice. J Korean Med Sci. 2005 Feb; 20(1):61-64.

11. Sisson T R C, Kendall N, Shaw E, Kechavarz-Oliai L. Phototherapy of jaundice in the newborn infant. II. Effect of various light intensities. The Journal of Pediatrics. 1972 July; 81(1): 35-38.

12. Wood A J J, Dennery P A, Seidman D S, Stevenson D K. Neonatal hyperbilirubinemia. N Engl J Med. 2001; 344(8): 581-590.

13. Nuntnarumit $P$, Naka C. Comparison of the effectiveness between the adapted-double phototherapy versus conventional-single phototherapy. J Med Assoc Thai. 2002 Nov; 85 (Suppl 4):S1159-1166.

14. Boonyarittipong $P$, Kriangburapa W, Booranavanich K. Effectiveness of double-surface intensive phototherapy versus single-surface intensive phototherapy for neonatal hyperbilirubinemia. J Med Assoc Thai 2008; 91(1):50-55.

15. Clarence W, Gowen J. Hyperbilirubinemia. In: Marcdante K J, Kliegman R M, Jenson H B, Behrman R $E$, editors. Nelson essential of pediatrics. $6^{\text {th }}$ ed. Saunders Elsevier; 2010.p. 247-250.

16. Sarici SU, Alpay F, Unay B, Ozcan O, Gökçay E. Double versus single phototherapy in term newborns with significant hyperbilirubinemia. J Trop Pediatr. 2000 Feb; 46(1):36-39.

17. Thaithumyanon $P$, Visutiratmanee $C$. Double phototherapy in jaundiced term infants with hemolysis. $J$ Med Assoc Thai. 2002; 85(11):1176-1781.

18. Kang $\mathrm{J} \mathrm{H}$, Shankaran S. Double phototherapy with high irradiance compared with single phototherapy in neonates with hyperbilirubinemia. Amer $\mathrm{J}$ Perinatol 1995; 12(3): 178-180. 